\title{
Fabrication and Irradiation Test Plan for Fully Ceramic Microencapsulated Fuels
}

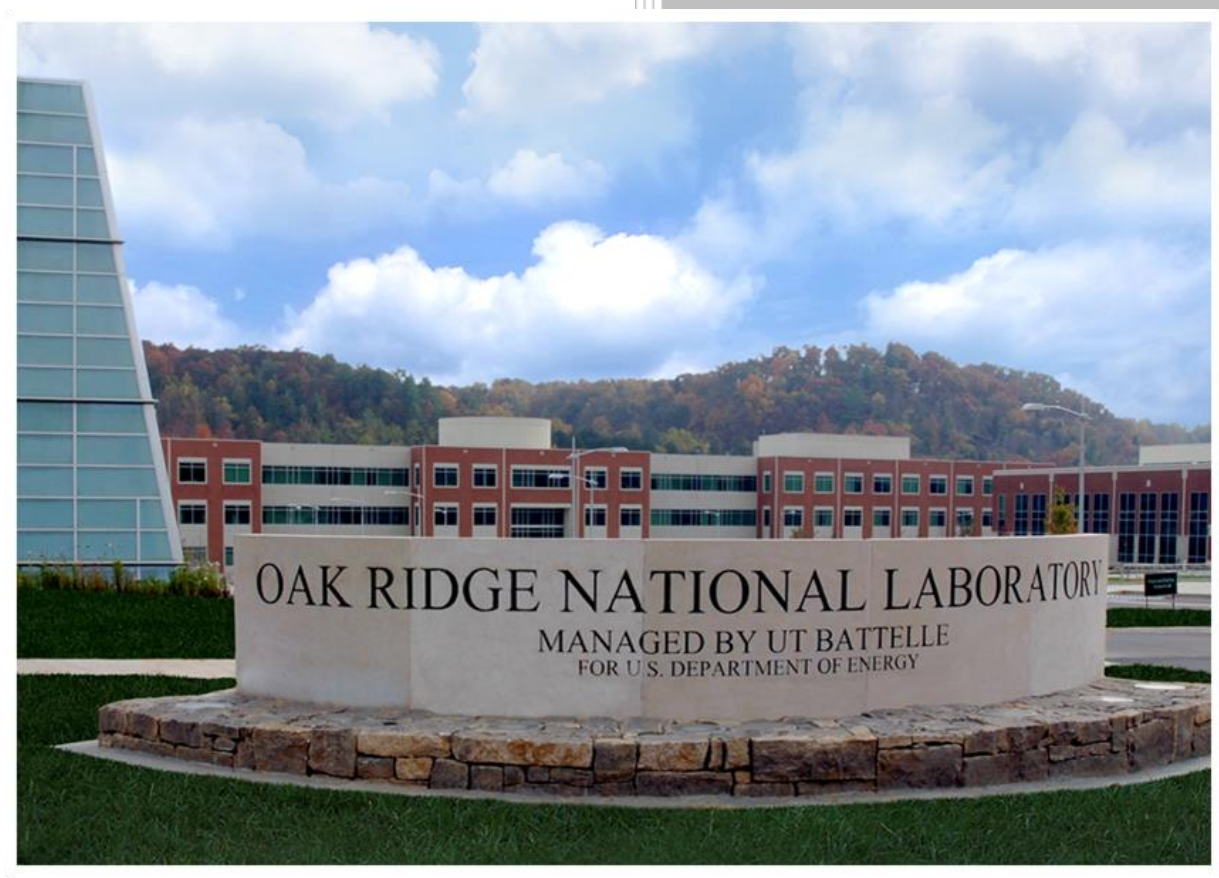

\section{Approved for public release.} Distribution is unlimited.
R. L. Seibert
K. A. Terrani
J. O. Kiggans
J. W. McMurray
B. C. Jolly
C. M. Petrie
A. T. Nelson

January 25, 2019 


\title{
DOCUMENT AVAILABILITY
}

Reports produced after January 1, 1996, are generally available free via US Department of Energy (DOE) SciTech Connect.

Website www.osti.gov

Reports produced before January 1,1996, may be purchased by members of the public from the following source:

\author{
National Technical Information Service \\ 5285 Port Royal Road \\ Springfield, VA 22161 \\ Telephone 703-605-6000 (1-800-553-6847) \\ TDD 703-487-4639 \\ Fax 703-605-6900 \\ E-mail info@ntis.gov \\ Website http://classic.ntis.gov/
}

Reports are available to DOE employees, DOE contractors, Energy Technology Data Exchange representatives, and International Nuclear Information System representatives from the following source:

Office of Scientific and Technical Information

PO Box 62

Oak Ridge, TN 37831

Telephone 865-576-8401

Fax 865-576-5728

E-mail reports@osti.gov

Website http://www.osti.gov/contact.html

This report was prepared as an account of work sponsored by an agency of the United States Government. Neither the United States Government nor any agency thereof, nor any of their employees, makes any warranty, express or implied, or assumes any legal liability or responsibility for the accuracy, completeness, or usefulness of any information, apparatus, product, or process disclosed, or represents that its use would not infringe privately owned rights. Reference herein to any specific commercial product, process, or service by trade name, trademark, manufacturer, or otherwise, does not necessarily constitute or imply its endorsement, recommendation, or favoring by the United States Government or any agency thereof. The views and opinions of authors expressed herein do not necessarily state or reflect those of the United States Government or any agency thereof. 
Advanced Fuels Campaign Program

\title{
FABRICATION AND IRRADIATION TEST PLAN FOR FULLY CERAMIC MICROENCAPSULATED FUELS
}

\author{
Rachel L. Seibert \\ Kurt A. Terrani \\ James O. Kiggans (Jr.) \\ Jake W. McMurray \\ Brian C. Jolly \\ Christian M. Petrie \\ Andrew T. Nelson
}

Date Published: January 25, 2019

Prepared by

OAK RIDGE NATIONAL LABORATORY

Oak Ridge, TN 37831-6283

managed by

UT-BATTELLE, LLC

for the

US DEPARTMENT OF ENERGY

under contract DE-AC05-00OR22725 



\section{CONTENTS}

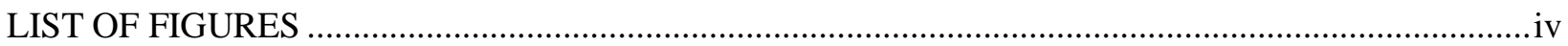

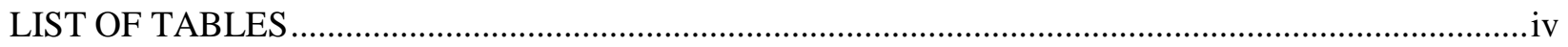

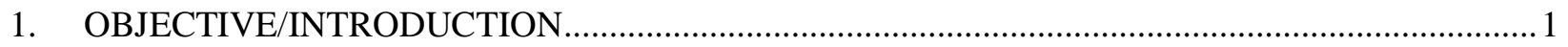

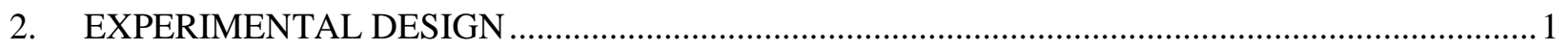

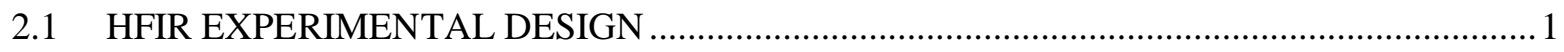

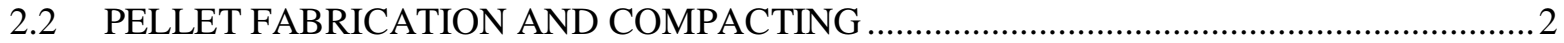

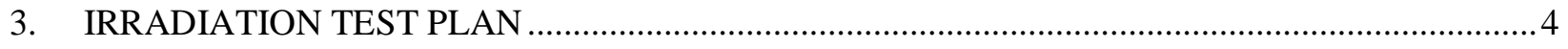

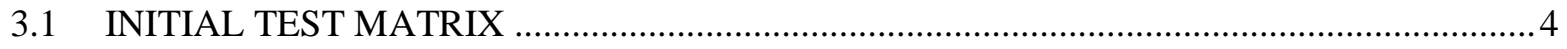

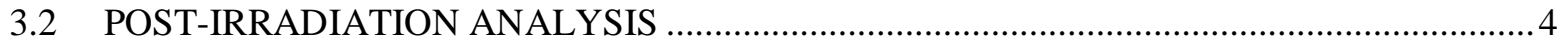

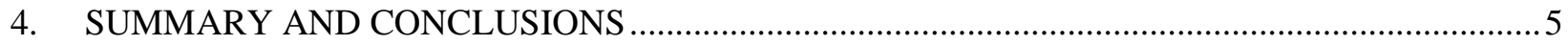

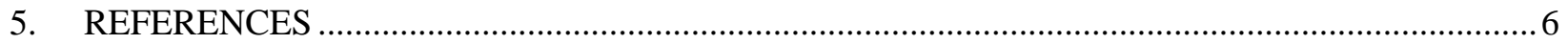




\section{LIST OF FIGURES}

Figure 1. Schema of the HFIR MiniFuel irradiation design from Petrie et al. [4]. ...................................2

Figure 2. Schema of the apparatus used to hot-press fuel pellets............................................................ 3

Figure 3. Example of one of the first pellets pressed ............................................................................ 3

Figure 4. Calculation of the number of HFIR cycles required to reach certain fuel burnup rates............... 4

\section{LIST OF TABLES}

Table 1. Summary of particles studied and their coating layer properties. ............................................. 2

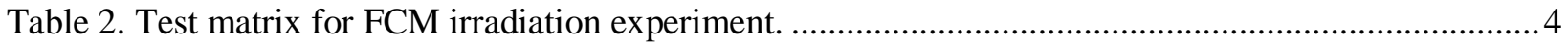




\section{OBJECTIVE/INTRODUCTION}

The objective of this work is to irradiate fully ceramic microencapsulated (FCM) fuel in the High Flux Isotope Reactor (HFIR) to (1) facilitate irradiation of novel fuel concepts and (2) validate potential fuel performance. The FCM fuel used in this study is composed of either uranium nitride (UN) or two phase uranium oxide and uranium carbide (UCO) kernels, each of which are coated with a tristructural-isotropic (TRISO) coating layer and compacted into a silicon carbide ( $\mathrm{SiC}$ ) matrix. The TRISO layers and matrix provide multiple barriers to fission product release. Five particles are placed into the matrix and, combined, are considered a single "pellet". This fuel concept is a candidate accident-tolerant fuel (ATF) for use in light water reactors (LWRs) and advanced reactor concepts. The potential benefits of the FCM fuel concept include greater burnup, improved fuel reliability, and improved thermal performance. The UN particles used in this fuel concept are intended to enhance heavy metal loading to achieve sustainable LWR cycle lengths. These kernels were developed and produced under the Advanced Fuels Campaign (AFC) at Oak Ridge National Laboratory (ORNL) beginning in FY15 [1], and coating parameters for UN were completed in FY16 [2,3]. Production of very high-density TRISO-coated UN kernels was completed more recently in FY18. The experiment described herein is being conducted to provide basic data on the irradiation performance of these fuel pellets at relevant LWR temperatures. This report presents the irradiation test plan for this novel fuel concept.

\section{EXPERIMENTAL DESIGN}

\subsection{HFIR EXPERIMENTAL DESIGN}

The HFIR experimental design uses the MiniFuel design as described in Petrie et al. [4] and summarized in the following section. Figure 1 shows a model of the irradiation targets and experiment facility. The design allows for the facility to accommodate nine targets, each with six specimen subcapsules. The capsules will be modified to accommodate a larger fuel volume by eliminating the molybdenum cup and modifying the tube geometry. Ultimately, each subcapsule contains a fabricated fuel pellet, a molybdenum tube, and $\mathrm{SiC}$ passive thermometry for use in post-irradiation evaluation of temperature. The temperature is controlled by varying the gas gap between the subcapsule and the target housing. Neutronics calculations will be performed to determine neutron and gamma heating rates in the fuel for predictions of the fuel burnup profile and for input regarding future thermal analysis. This activity is currently in progress. 


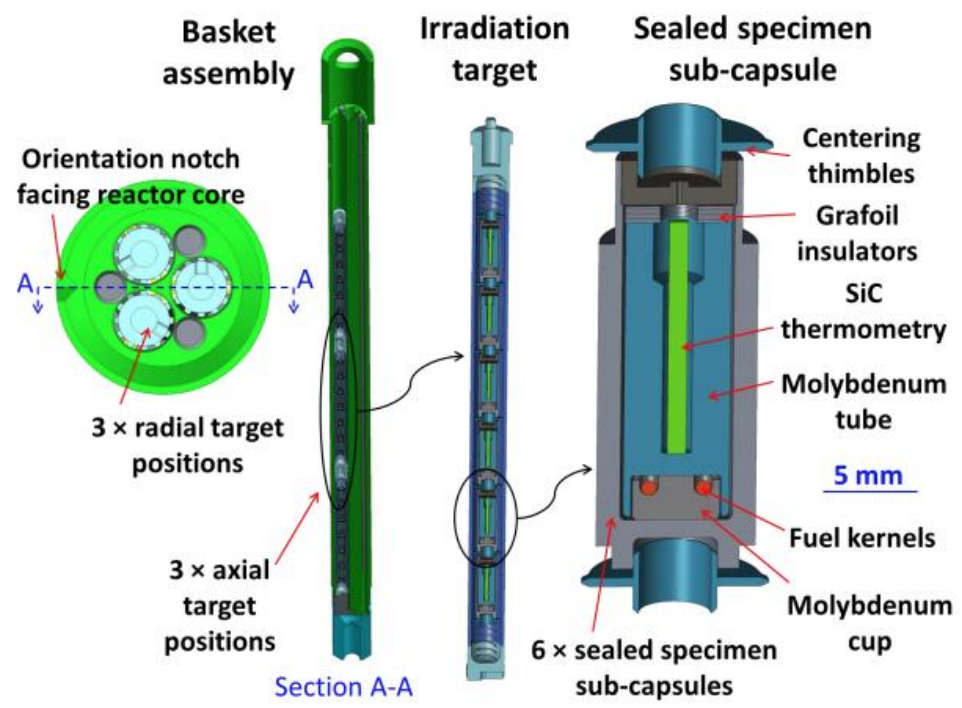

Figure 1. Schema of the HFIR MiniFuel irradiation design from Petrie et al. [4]. For this experiment, a pellet with a $\mathrm{SiC}$ matrix will be used in the place of the molybdenum cup holding fuel kernels.

\subsection{PELLET FABRICATION AND COMPACTING}

Pellets will be fabricated using a method based upon a previously developed hot-press approach [5-7]. Three types of particles will be used: TRISO-coated UN particles of low and high density, and TRISOcoated UCO particles, some properties of which are listed in Table 1. The UN kernels are from the batch prepared previously (FCM-4A-UN31K), details of which are available in Jolly et al. [3] for kernel fabrication and coating. The low density set of particles will be taken from the FCM-4A-UN31K-02T batch prepared previously. Particles have an average diameter of $810 \mu \mathrm{m}$ [8].

Table 1. Summary of particles studied and their coating layer properties.

\begin{tabular}{lcc}
\hline & $\begin{array}{c}\text { UN - low } \\
\text { density }\end{array}$ & UCO \\
\hline Kernel diameter $(\mu \mathrm{m})$ & 810.4 & 425.0 \\
Density $\left(\mathrm{g} / \mathrm{cm}^{3}\right)$ & 12.49 & 10.97 \\
Kernel theoretical density $(\%)$ & 87.2 & 96.5 \\
${ }^{235}$ U enrichment $(\mathrm{wt} . \%)$ & 0.22 & 0.71 \\
Buffer thickness $(\mu \mathrm{m})$ & 93 & 100 \\
IPyC thickness $(\mu \mathrm{m})$ & 39 & 43 \\
SiC thickness $(\mu \mathrm{m})$ & 30 & 36 \\
OPyC thickness $(\mu \mathrm{m})$ & 42 & 41 \\
\hline
\end{tabular}

Particles will be coated with a $\mathrm{SiC}$ slurry prior to being pressed into a pellet. This low-viscosity slurry consists of three $\mathrm{SiC}$ powders of varying particle size (Nanomakers, France, Lot \#12-SiC-122 with $<100 \mathrm{~nm}$ grain size; $0.5-1 \mu \mathrm{m}$ H.C. Starck Beta-SiC Grade BF12-A; and US Research Nano materials $2 \mu \mathrm{m} \mathrm{SiC} \mathrm{powder)} \mathrm{mixed} \mathrm{with} \mathrm{yttria-alumina} \mathrm{as} \mathrm{sintering} \mathrm{aides} \mathrm{suspended} \mathrm{in} \mathrm{ethanol.} \mathrm{The} \mathrm{powders} \mathrm{are}$ added at a ratio of $0.55 \mathrm{Y}_{2} \mathrm{O}_{3}: \mathrm{Al}_{2} \mathrm{O}_{3}$. This slurry process has been modified only slightly from the previously determined recipe $[6,7]$ to optimize adhesion to kernels. The purpose of this transient liquid 
phase sintering of nano-SiC is to bond TRISO particles into the SiC matrix by densification using hot pressing.

UN TRISO particles and the slurry are nano-coated using a method described by Terrani et al. [9]. In summary, they are coated using a custom-built rotating chamber heated to an average of $80{ }^{\circ} \mathrm{C}$ using a hot air blower. The slurry is sprayed on the particles at approximately $1.25 \mathrm{ml}$ per minute, and coating is assisted with an ultrasonic generator atomizing nozzle. Progress is monitored by interrupting the coating process to weigh the particles until the final desired weight is achieved.

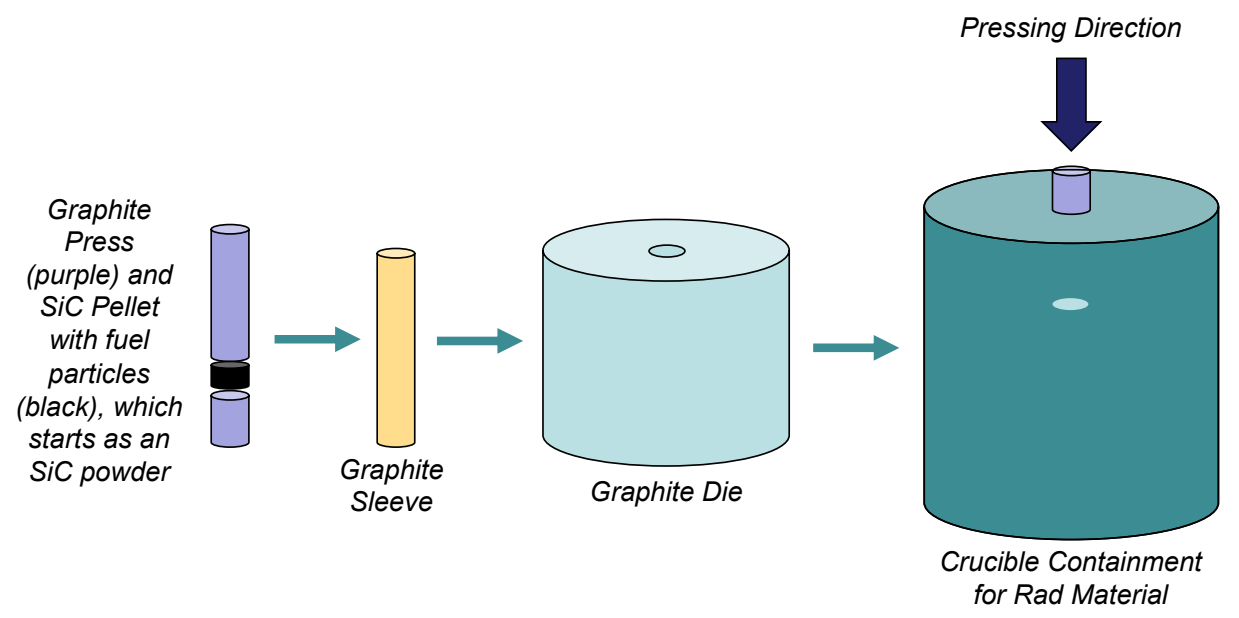

Figure 2. Schema of the apparatus used to hot-press fuel pellets.

Once particles are coated, they are ready to be pressed into a pellet of $5.8 \mathrm{~mm}$ diameter and $2.8 \mathrm{~mm}$ height. The setup used for hot pressing pellets consists of a graphite die, a graphite sleeve, and graphite presses. The graphite sleeve is used as a lubricant to facilitate pellet removal after hot pressing and is disposable. The sleeve is placed inside the die, followed by $0.1 \mathrm{~g}$ of SiC powder, five coated TRISO UN fuel particles, and another $0.2 \mathrm{~g}$ of $\mathrm{SiC}$ powder. This whole die apparatus is loaded inside of a crucible for containment of radiological specimen as shown in Figure 2. A hole has been made in the lid of the crucible to allow for the press to go through, making the crucible secondary containment. Pellets are pressed using a Brew vacuum furnace hot press held at $1800{ }^{\circ} \mathrm{C}$ for 30 minutes in -10 " argon with a pressure of 9.5 $\mathrm{MPa}$. An example of the final product using surrogate particles is shown in Figure 3. The final weight of the particles will be recorded and should be comparable to weights obtained in studies conducted by Terrani et al. [9], which had a final coating-to-particle ratio of 1.05 and a pellet particle packing fraction of $38 \mathrm{vol} . \%$. The same process will be used with TRISO UCO, but due to smaller kernel size more than five particles will be used. A minimum total of 15 pellets will be pressed, 2 for each type per irradiation condition and a minimum of 1 of each type to be examined without irradiation.

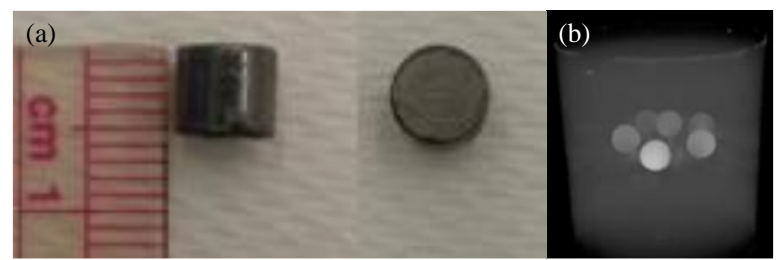

Figure 3. Example of one of the first pellets pressed: (a) pellet dimensions illustrated at $5.8 \mathrm{~mm}$ in diameter and $5 \mathrm{~mm}$ high (optimized pellets are only $2.8 \mathrm{~mm}$ high); (b) tomography image of the pellet showing six surrogate $\mathrm{ZrO}_{2}$ kernels along the central plane of the $\mathrm{SiC}$ matrix. 


\section{IRRADIATION TEST PLAN}

\subsection{INITIAL TEST MATRIX}

This experiment will test high-density UN fuel that has been hot pressed into a pellet with a SiC matrix. The test matrix is summarized in Table 2. All fuels tested use natural or depleted uranium. All UN fuel was from the same feedstock (FCM-4A-UN31K) and will be tested at $500{ }^{\circ} \mathrm{C}$ and at burnups of 1 and $3 \%$ fissions per initial metal atom (FIMA), which will correspond to approximately 3 and 8 HFIR cycles, respectively, as shown in Figure 4. These calculations will be re-run for the FCM specific setup to verify the necessary in-reactor time to reach the desired burnups. More details regarding fuel fabrication can be found in the previous section.

Table 2. Test matrix for FCM irradiation experiment.

\begin{tabular}{lccc}
\hline \multicolumn{1}{c}{ Fuel form } & \# pellets & Target temperature $\left({ }^{\circ} \mathbf{C}\right)$ & $\begin{array}{c}\text { Target burnup } \\
(\% \text { FIMA) }\end{array}$ \\
\hline TRISO-coated $\mathrm{UN}_{0.75} \mathrm{C}_{0.25}$ kernels (low density) & 2 & 500 & $1 \%$ \\
\multirow{2}{*}{ TRISO-coated UCO } & 2 & 500 & $3 \%$ \\
& 2 & 500 & $1 \%$ \\
& 2 & 500 & $3 \%$ \\
\hline
\end{tabular}

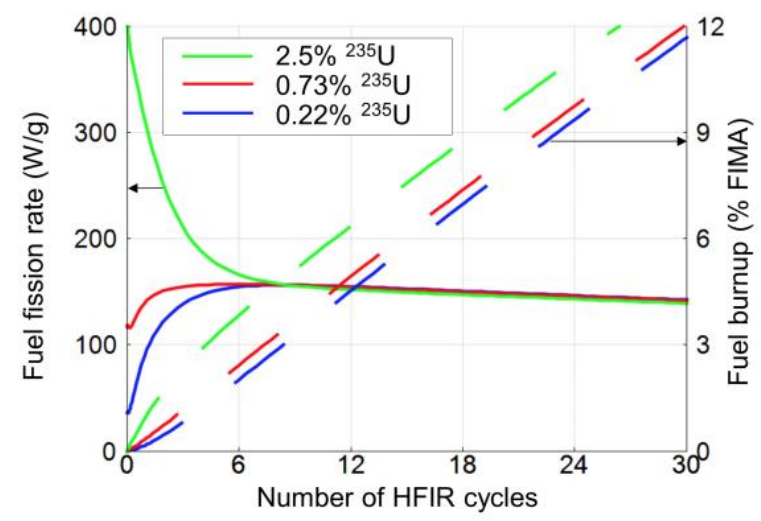

Figure 4. Calculation of the number of HFIR cycles required to reach certain fuel burnup rates (Used with permission from Petrie et. al. 2018 [4]).

\subsection{POST-IRRADIATION ANALYSIS}

Deconsolidation of the irradiation capsules will take place in the Irradiated Fuels Examination Laboratory (IFEL), a hot-cell facility at ORNL. Post-irradiation analysis will be performed in both IFEL and the Low Activation Materials Development and Analysis (LAMDA) lab at ORNL. Fission gas release is not expected but gamma spectroscopy measurements will be taken on the samples. X-ray tomography will be used to examine the integrity of the coating layers. Dimensional inspection and microstructural characterization will be conducted in LAMDA. Depending on the state of the fuel, further studies will be considered. Initial studies on nonirradiated samples are currently being conducted to establish a baseline for comparison to the irradiated specimen. 


\section{SUMMARY AND CONCLUSIONS}

This report summarizes the irradiation plan and fabrication of fully ceramic microencapsulated particle fuel in $\mathrm{SiC}$ matrix pellets. This experiment is based on a recently demonstrated design concept for miniature fuel irradiation experiments detailed in Petrie et al. [4]. The experiment contains three TRISOcoated fuel forms pressed into a $\mathrm{SiC}$ matrix. The intent is to evaluate the samples post-irradiation to determine swelling, fission gas release, and microstructural evolution as a function of burnup. The data to be obtained from the post-irradiation examination will be used to support the evaluation of the FCM fuel concept for LWR applications to ultimately improve accident tolerance and operational efficiency. 


\section{REFERENCES}

[1] T. B. Lindemer et al., "Quantification of process variables for carbothermic synthesis of UC1-xNx fuel microspheres," J. Nucl. Mater., vol. 483, pp. 176-191, 2017.

[2] B. Jolly, G. Helmreich, K. Cooley, J. Dyer, and K. Terrani, "Fabrication and Characterization of Surrogate TRISO Particles Using 800um ZrO2 Kernels,” ORNL/LTR-2016/315, 2016.

[3] B. Jolly, G. Helmreich, J. Dyer, and K. Terrani, "Fabrication and Characterization of DU and LEU UN TRISO Particles," ORNL/LTR-2016/384, 2016.

[4] C. M. Petrie, J. R. Burns, R. N. Morris, K. R. Smith, A. G. Le Coq, and K. A. Terrani, "Irradiation of Miniature Fuel Specimens in the High Flux Isotope Reactor," ORNL/SR-2018/874, 2018.

[5] L. L. Snead, K. A. Terrani, Y. Katoh, C. Silva, K. J. Leonard, and A. G. Perez-Bergquist, "Stability of SiC-matrix microencapsulated fuel constituents at relevant LWR conditions," J. Nucl. Mater., vol. 448, pp. 389-398, 2014.

[6] K. A. Terrani et al., "Fabrication and characterization of fully ceramic microencapsulated fuels," J. Nucl. Mater., vol. 426, no. 1-3, pp. 268-276, 2012.

[7] K. A. Terrani, J. O. Kiggans, C. M. Silva, C. Shih, Y. Katoh, and L. L. Snead, "Progress on matrix $\mathrm{SiC}$ processing and properties for fully ceramic microencapsulated fuel form," J. Nucl. Mater., vol. 457, pp. 9-17, 2015.

[8] J. W. McMurray, J. O. Kiggans, G. W. Helmreich, and K. A. Terrani, "Production of near-full density uranium nitride microspheres with a hot isostatic press," J. Am. Ceram. Soc., vol. 101, no. 10, pp. 4492-4497, 2018.

[9] K. Terrani, M. Trammell, J. Kiggans, D. Skitt, and B. Jolly, "UN TRISO Compaction in SiC for FCM Fuel Irradiations," ORNL/LTR-2016/702, 2016. 